\title{
Fishes of the Du Chaillu Massif, Niari Depression, and Mayombe Massif (Republic of Congo, west-central Africa): A list of species collected in tributaries of the upper Ogowe and middle and upper Kouilou-Niari River basins
}

\author{
Victor Mamonekene ${ }^{1}$ and Melanie L.J. Stiassny ${ }^{2 *}$ \\ 1 Institut de Développement Rural, Université Marien Ngouabi, B.P. 69, Brazzaville, Republic of Congo. \\ 2 American Museum of Natural History, Department of Ichthyology, Central Park West at 79th Street, New York, New York 10024. \\ * Corresponding author. E-mail: mljs@amnh.org
}

\begin{abstract}
A list of fishes collected in rivers of the Du Chaillu Massif, Niari Depression, and Mayombe Massif in the Republic of Congo is provided. Few previous collections have been made and the region is poorly known ichthyologically, however several large mining projects are under development while logging and artisanal gold mining is already underway. One hundred and two species distributed in 22 families are reported, and 11 of these represent putatively new species. The high number of undescribed species recorded in the present study serves to highlight the importance of efforts to fully document the region's ichthyofauna prior to the realization of major infrastructure projects that will undoubtedly impact aquatic habitats.
\end{abstract}

\section{INTRODUCTION}

The study regions on the Du Chaillu Massif, Niari Depression and Mayombe Massif are situated in the southwest of the Republic of Congo from the main channel of the Kouilou-Niari River to the Gabonese border (Figure 1). The relief of the Du Chaillu Massif consists of a metamorphic formation incised by steep-sloped hills and high mountainous regions. Most of the massif is covered in dense forest with savanna formations interspersed, although these are mainly restricted to the eastern parts. The Niari depression is a flat savannah area on a calcareous substrate, while the Mayombe Massif is mountainous with numerous deeply incised valleys covered with dense forest on a metamorphic substrate (Vicat and Gioan 1989).

The main rivers draining the area are the Ogowe and the Kouilou-Niari. Seventeen stations are reported on, and include two sites on the Mayombe Massif (Table 1, sites 1-2). In the Niari Depression the main channel of the middle Kouilou-Niari and two of its smaller tributaries were sampled (Table 1, sites 3-6). The upper Louessé River, which itself is one of the major right bank tributaries of the Kouilou-Niari River, was sampled in the main channel and tributaries (Table 1, sites 7-12), as were headwater tributaries of the Ogowe River (Table 1, sites 13-17). Several major mining projects are currently under development in the region, and ongoing logging and gold prospecting are contributing to a steady degradation of the environment (Figure 2). Data on the fish fauna of the whole country is fragmented (Stiassny et al. 2007), and the study region had until recently never been explored ichthyologically. For the present study fishes were collected during surveys undertaken as part of social and environmental impact assessments mandated prior to the implementation of major iron mining projects and associated road and rail development. Here we report on the first ichthyological collections from the region.

\section{Materials ANd Methods}

The list of species provided is based on collections made during the rainy seasons of 2010 and 2011. Headwater streams of the Ogowe River and the Kouilou-Niari main channel and adjacent tributaries were sampled between November and December 2010 and again in December 2011. For the upper Louesse River localities, fishes were collected later in the rainy season between March and April 2012. Sampling was not conducted continuously along any river, and localities were surveyed based on accessibility or for specific assessment purposes (Figure 1, Table 1). Fishes were collected and euthanized prior to preservation in accordance with recommended guidelines for the use of fishes in research (AFS/AIFRB/ASIH, 2003). All materials are housed in the Ichthyology Department of the American Museum of Natural History (AMNH), New York, and associated data are accessible at http:// entheros.amnh.org/db/emuwebamnh/

\section{Notes on Collection Sites}

Site 1 (Sounda, Figure 3A) the Kouilou-Niari flows through a narrow gorge on the Mayombe Massif at the site of the proposed Sounda dam, the river ranges in width from $50 \mathrm{~m}$ at the dam site to $300 \mathrm{~m}$ at the exit of the gorge. Riverbanks are steep and the substrate rocky with rapid current. Site 2 (Passi Passi Creek, Figure 3B) a small savannah river traversing the eastern foothills of the Mayombe Massif. At the collection site its width is about 3 $\mathrm{m}$, flowing over gravel and mud. Site 3 (near Pont-du-Niari, Figure 3C) the Kouilou-Niari has a width of over $100 \mathrm{~m}$ and flows with medium current through savannah, with intact gallery forest lining the banks. Site 4 (Loudima, Figure 3D) at the bridge of Loudima the Kouilou-Niari is about 200 
m wide, flowing with a strong current and high turbidity due to erosion of clay banks. Surrounding vegetation is savannah, and much of the gallery forest is degraded. Site 5 (Lekoumou River, Figure 3E) a small tributary of the Kouilou-Niari with its source in the Du Chaillu Massif. In the section surveyed, the river has an average width of 20 $m$ with steep undisturbed, forested banks. Water velocity is medium, with high sediment load and shoreline sediments predominately of silt and sand. Site 6 (Gnimi River, Figure 3F) a small tributary of about $3 \mathrm{~m}$ in width and less than 1 $\mathrm{m}$ deep at the sample site. The river flows through swamp forest degraded by slash and burn agriculture. Site 7 (Louesse, Figure 3G) the upper Louesse River in the region of Mayoko is 60 meters wide with a depth intermittently exceeding $6 \mathrm{~m}$, it is joined by a shallow creek where water is diverted to Mayoko village. The banks are flooded and colonized by Raphia. Site 8 (Lipia Creek, Figure 3H) flows alongside the village of Mayoko. The upstream portion of the creek is maximally $2 \mathrm{~m}$, where it flows through flooded forest. Water is black with moderate flow over mud substrate with much accumulated plant debris. Site 9 (Leala River, Figure 4A) a large left bank tributary of the Louesse River, north of Mayoko. At the sampling site the river narrows to $6 \mathrm{~m}$ width with a maximum depth of $2 \mathrm{~m}$. Site 10 (Mayoko Creek 1, Figure 4B) this unnamed creek is a tributary of the Mandoro (itself a large left bank tributary of the Louesse River) running alongside the Mayoko Iron Ore deposit. At the sampling site the creek is 1-2 m wide and shallow. Gold panning sites are observed all along the creek resulting in a highly disturbed reach.

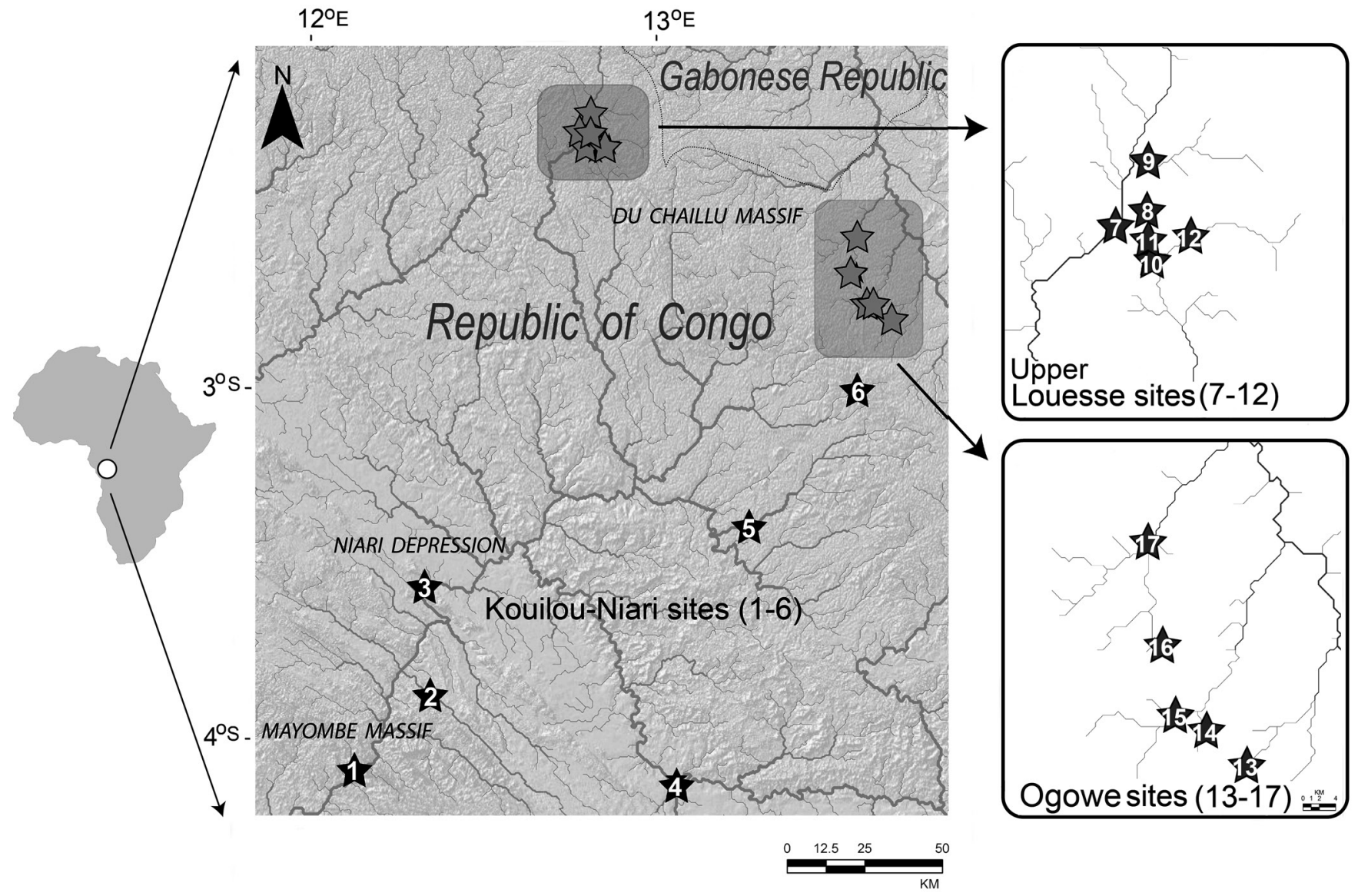

FIGURE 1. Location of study regions in the Republic of Congo, with upper Louesse and Ogowe sites inset (rhs).
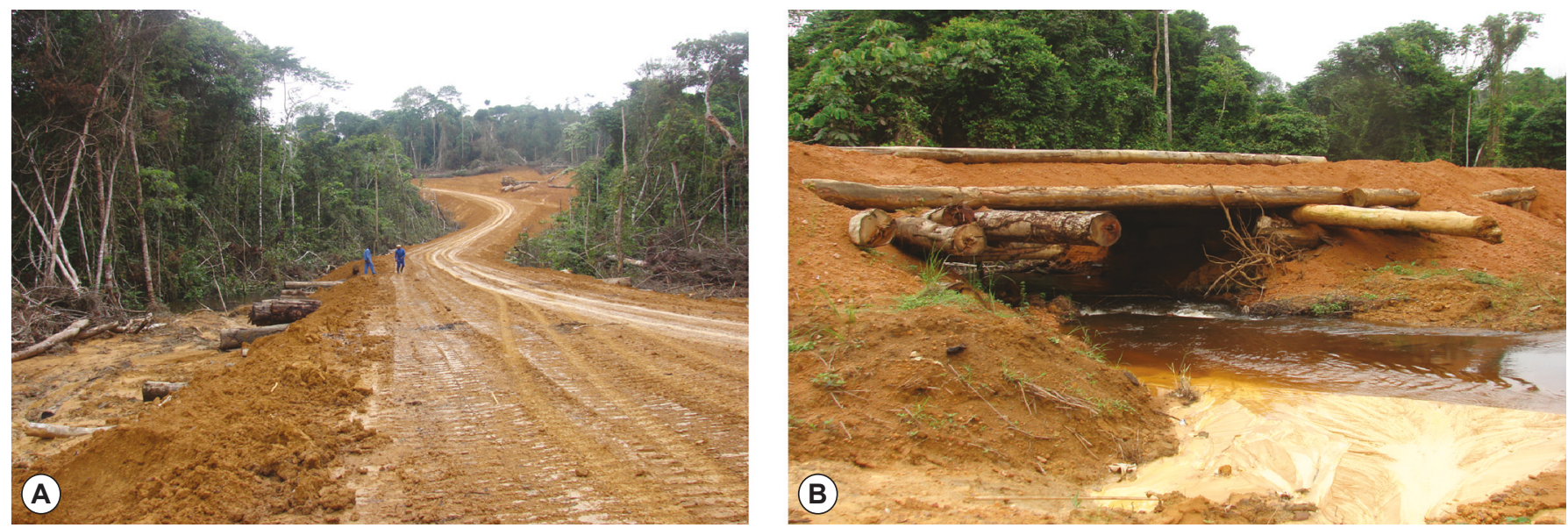

FIGURE 2. Habitat degradation, A) forest clearance for logging road; B) bridge construction for logging road resulting in bank erosion and sedimentation. 
Site 11 (Mayoko Creek 2, Figure 4C) the same creek was sampled upstream in a region with minimal disturbance to the forest cover and less gold panning. Site 12 (Mandoro River, Figure 4D) the main channel of the Mandoro River was sampled upstream of the Mayoko Iron Ore deposits in a remote region distant from human habitation. The river is $15 \mathrm{~m}$ wide at the sampling site, and flows through dense canopy forest. Site 13 (Lefou River, Figure 4E) is a black water tributary of the Ogowe near the city of Zanaga. It flows entirely through dense forest. At the sampling site its width is about $1.5 \mathrm{~m}$ with a few swampy sections. Site 14 (Leweme Creek, Figure 4F) is between 1 to $2 \mathrm{~m}$ wide, but in places expands to over $6 \mathrm{~m}$ forming large pools. The creek flows rapidly through dense forest with a muddy substrate upstream, but downstream the outcropping bedrock causes the exposure of large blocks of rock. Site 15 (Dzoussounou Creek, Figure 4G) is situated in the main area of iron ore exploration and logging. The creek is about $3 \mathrm{~m}$ wide and shallow, in most places not exceeding 0.5 $\mathrm{m}$ deep. At the surveyed sites water flow was rapid over gravel and sand. Site 16 (Lebayi Creek, Figure 4H) a small black water stream originating on Mount Lebayi and flowing through dense forest in a succession of falls under a closed canopy. Site 17 (Djoulou River, Figure 5A) flows under forest canopy and includes flood zones. Width is about $15 \mathrm{~m}$ and depth of more than $2 \mathrm{~m}$ in places, with medium flow over mud and sand.

\section{Fish sampling}

Standard fishing techniques were employed (Lang and Baldwin, 1996), and depending on habitat and conditions, included the deployment of monofilament gill nets, electrofishing (Figure 5B), dip, cast, and scoop nets (Figure
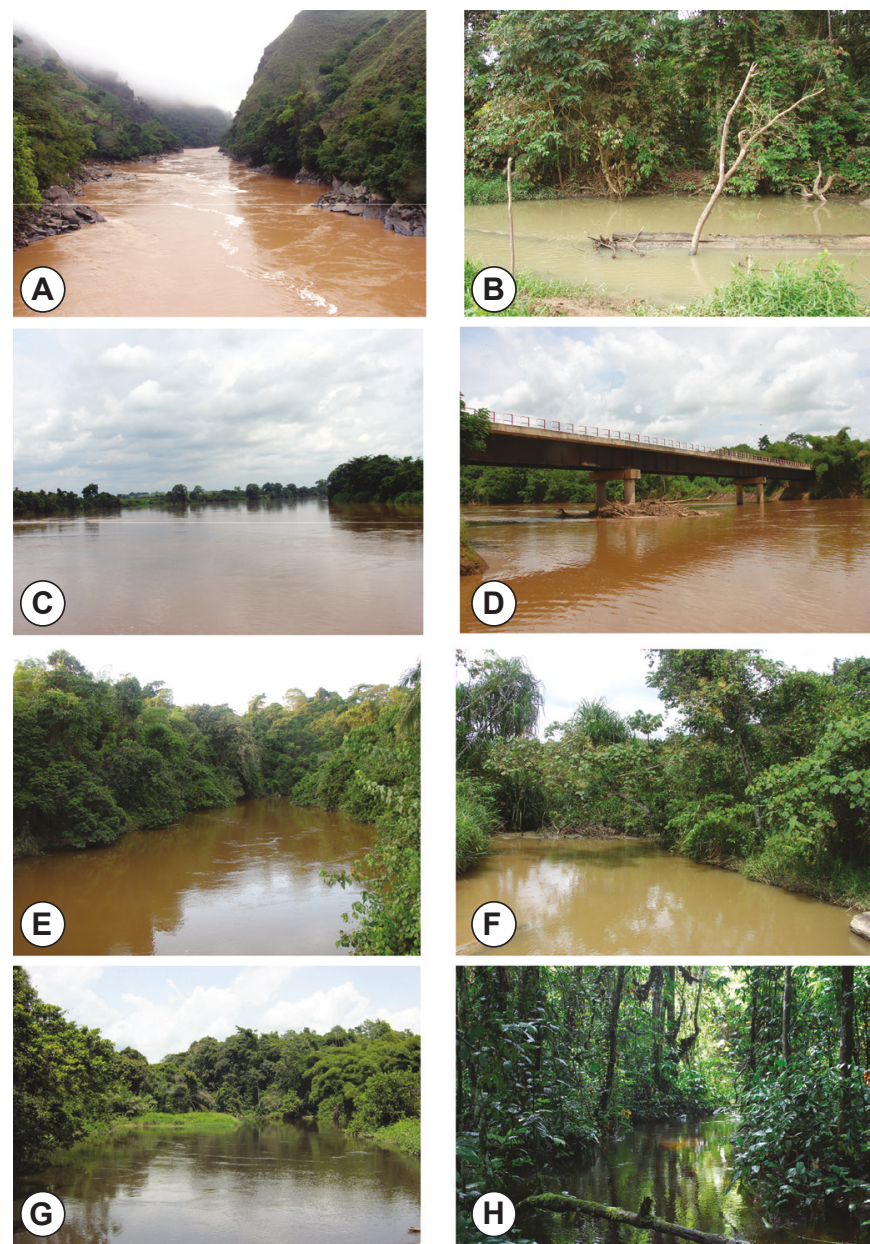

FigurE 3. Sampling sites: A) Kouilou Niari at Sounda; B) Passi-Passi Creek; C) Kouilou Niari near Pont-du- Niari; D) Kouilou Niari at Loudima bridge; E) Lekoumou River; F) Gnimi River; G) Louesse River near Mayoko; H) Lipia Creek.

TABLE 1. Coordinates and site data.

\begin{tabular}{|c|c|c|c|c|c|}
\hline SITE & LOCALITY & CoORdinates & BASIN & SUBSTRATE & COVER \\
\hline 1 & Sounda & $04^{\circ} 04^{\prime} 48.54^{\prime \prime} \mathrm{S}, 12^{\circ} 08^{\prime} 18.38^{\prime \prime} \mathrm{E}$ & Kouilou-Niari & Rocks, gravel and sand & Gallery Forest, Steep incline \\
\hline 2 & Passi-Passi Creek & $03^{\circ} 51^{\prime} 58.39^{\prime \prime} \mathrm{S}, 12^{\circ} 20^{\prime} 47.22^{\prime \prime} \mathrm{E}$ & Kouilou-Niari & Gravel and mud & $\begin{array}{l}\text { Savannah, fringing shrubs and } \\
\text { grasses }\end{array}$ \\
\hline 3 & Pont du Niari & $03^{\circ} 33^{\prime} 22.68^{\prime \prime} \mathrm{S}, 12^{\circ} 20^{\prime} 32.57^{\prime \prime} \mathrm{E}$ & Kouilou-Niari & Gravel, mud and sand & Savannah, fringing forest \\
\hline 4 & Loudima & $04^{\circ} 06^{\prime} 1.44^{\prime \prime} \mathrm{S}, 13^{\circ} 03^{\prime} 38.16^{\prime \prime} \mathrm{E}$ & Kouilou-Niari & Clay and gravel & $\begin{array}{l}\text { Savannah, fringing shrubs and } \\
\text { grasses }\end{array}$ \\
\hline 5 & Lekoumou River & $03^{\circ} 22^{\prime} 49.30^{\prime \prime} \mathrm{S}, 13^{\circ} 15^{\prime} 55.01^{\prime \prime} \mathrm{E}$ & Kouilou-Niari & Silt and sand & Dense Forest \\
\hline 6 & Gnimi River & $02^{\circ} 59^{\prime} 41.06^{\prime \prime} \mathrm{S}, 13^{\circ} 34^{\prime} 43.22^{\prime \prime} \mathrm{E}$ & Kouilou-Niari & Sand and silt & Degraded swamp forest \\
\hline 7 & Louesse, nr Mayoko & $02^{\circ} 17^{\prime} 28.02^{\prime \prime} \mathrm{S}, 12^{\circ} 47^{\prime} 36.48^{\prime \prime} \mathrm{E}$ & $\begin{array}{l}\text { Louesse } \\
\text { (Kouilou-Niari) }\end{array}$ & Mud and sand & $\begin{array}{l}\text { Degraded swamp forest, } \\
\text { Rhaphia, emergent grasses }\end{array}$ \\
\hline 8 & Lipia Creek & $02^{\circ} 16^{\prime} 58.02^{\prime \prime} \mathrm{S}, 12^{\circ} 49^{\prime} 10.62^{\prime \prime} \mathrm{E}$ & $\begin{array}{l}\text { Louesse } \\
\text { (Kouilou-Niari) }\end{array}$ & Mud and plant debris & Flooded forest \\
\hline 9 & Leala River & $02^{\circ} 13^{\prime} 16.44^{\prime \prime} \mathrm{S}, 12^{\circ} 49^{\prime} 6.48^{\prime \prime} \mathrm{E}$ & $\begin{array}{l}\text { Louesse } \\
\text { (Kouilou-Niari) }\end{array}$ & Sand and gravel & Swamp forest, fringing grasses \\
\hline 11 & Mayoko Creek 2 & $02^{\circ} 18^{\prime} 0.78^{\prime \prime} \mathrm{S}, 12^{\circ} 49^{\prime} 23.40^{\prime \prime} \mathrm{E}$ & $\begin{array}{l}\text { Louesse } \\
\text { (Kouilou-Niari) }\end{array}$ & Rocks, sand and gravel & Closed canopy, dense forest \\
\hline 12 & Mandoro River & $02^{\circ} 17^{\prime} 59.16^{\prime \prime} \mathrm{S}, 12^{\circ} 51^{\prime} 59.10 \mathrm{E}$ & $\begin{array}{l}\text { Louesse } \\
\text { (Kouilou-Niari) }\end{array}$ & Rocks and sand & Closed canopy, dense forest \\
\hline 13 & Lefou River & $02^{\circ} 48^{\prime} 2.45^{\prime \prime} \mathrm{S}, 13^{\circ} 40^{\prime} 44.98^{\prime \prime} \mathrm{E}$ & Ogowe & Mud, sand and clay & Dense forest \\
\hline 14 & Leweme Creek & $02^{\circ} 45^{\prime} 55.62^{\prime \prime} \mathrm{S}, 13^{\circ} 37^{\prime} 54.12^{\prime \prime} \mathrm{E}$ & Ogowe & $\begin{array}{l}\text { Large boulders interspersed } \\
\text { with sand and mud }\end{array}$ & Dense forest \\
\hline 15 & Dzoussounou Creek & $02^{\circ} 45^{\prime} 7.68^{\prime \prime} \mathrm{S}, 13^{\circ} 36^{\prime} 25.68^{\prime \prime} \mathrm{E}$ & Ogowe & Gravel and sand & $\begin{array}{l}\text { Degraded forest, iron ore } \\
\text { exploration and logging }\end{array}$ \\
\hline 16 & Lebayi Creek & $02^{\circ} 39^{\prime} 52.32^{\prime \prime} \mathrm{S}, 13^{\circ} 34^{\prime} 46.62^{\prime \prime} \mathrm{E}$ & Ogowe & Rocks, gravel and sand & Dense Forest \\
\hline 17 & Djoulou River & $02^{\circ} 33^{\prime} 31.79^{\prime \prime} \mathrm{S}, 13^{\circ} 34^{\prime} 29.96^{\prime \prime} \mathrm{E}$ & Ogowe & Mud and sand & Dense Forest, fringing swamps \\
\hline
\end{tabular}



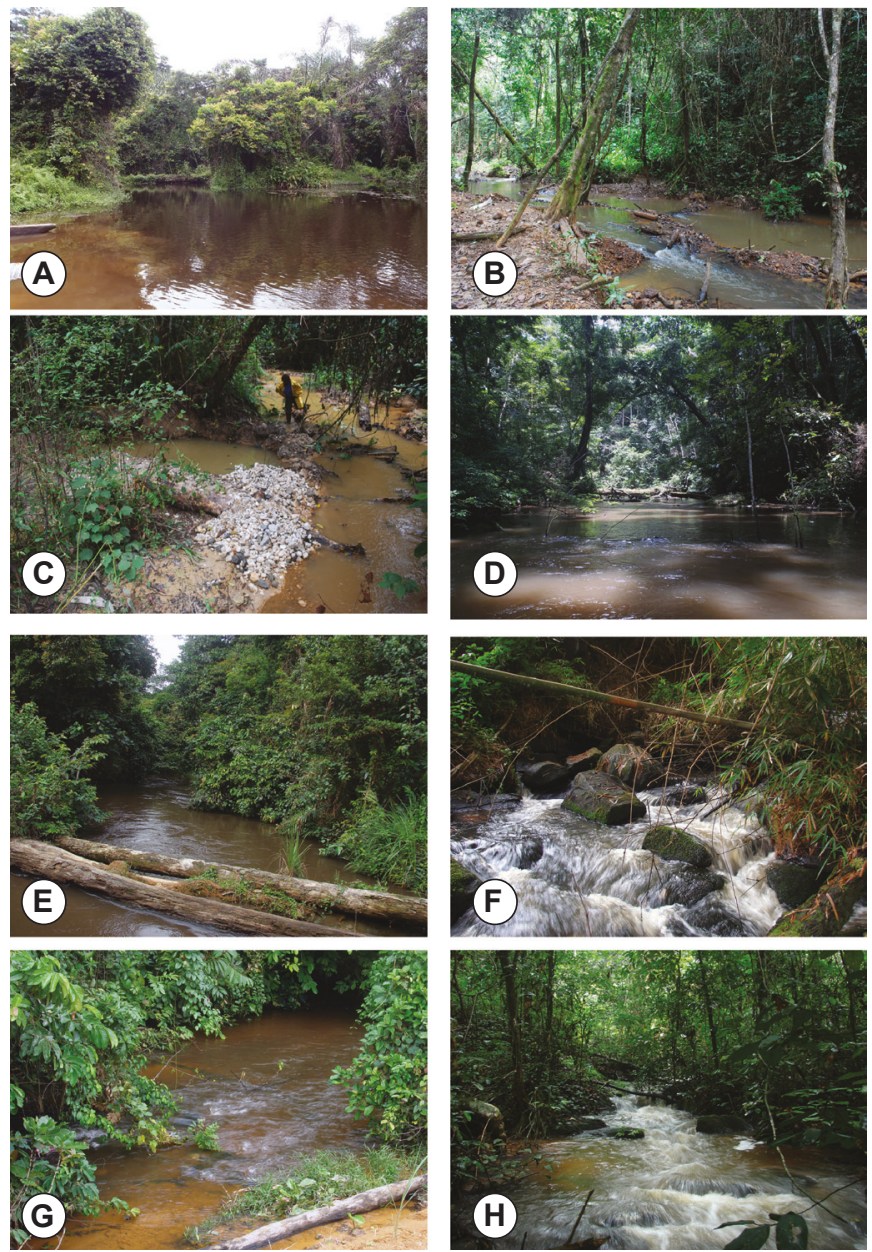

FiguRE 4. Sampling sites: A) Leala River; B) Mayoko Creek 1; C) Mayoko Creek 2; D) Mandoro River; E) Lefou River; F) Leweme Creek; G) Dzoussounou Creek; H) Lebayi Creek.
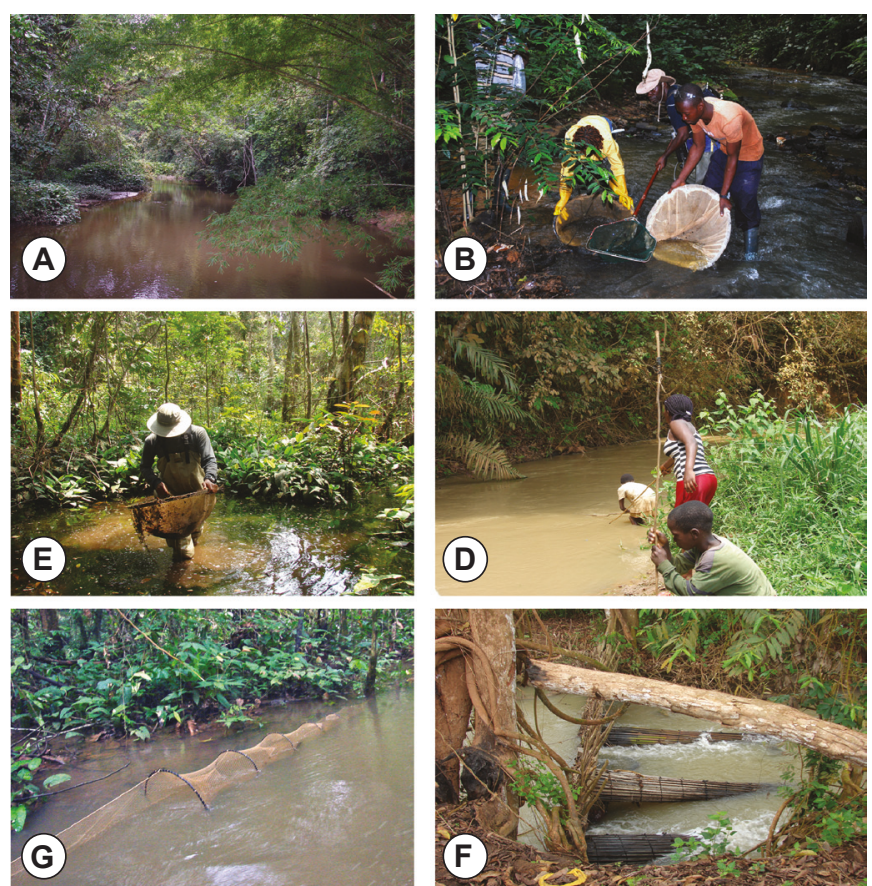

Figure 5. Sampling sites and fishing techniques: A) Djoulou River: B) Electrofishing, C) Use of scoop net, D) hook and line fishing E) Fyke net; F) local barrage traps.
5C), hook and line (Figure 5D), fyke nets (Figure 5E), and locally made barrage traps (Figure $5 \mathrm{~F}$ ). Interestingly there is no well-developed fishing culture among the peoples of this part of the Republic of Congo who instead have relied for millennia on the capture of bush meat as their major protein source. While women and children do fish on a small scale, mostly with hook and line (Figure 5D), and occasionally with barrage traps, during the present surveys the only river where any evidence of sustained artisanal fishing was found was in the Djoulou River (site 17, Figure 5A), where two fishing pirogues were observed. Taxonomic nomenclature used herein follows Brooks et al. (2011), which is based primarily on Eschmeyer (2010) but with a few modifications. All fishes were collected and exported with permission of the Congolese Ministère du Développement Durable et de l'Economie Forestière, Direction de l'Economie Forestière (Permit\# 178465 and Permit\# 1125526, both on file at AMNH).

\section{RESULTS AND DiscusSion}

A total of 1250 individuals belonging to 102 species, distributed in 22 families and nine orders are represented in Table 2, with their distribution among sites indicated in columns 1-17. Most likely in reflection of the paucity of previous sampling in this region, most of the species captured in the present study represent new distributional records, many for the entire country, but for most their presence is not unanticipated given recorded occurrences in adjacent regions (Stiassny et al. 2007; Brooks et al. 2011). A few taxa however, do represent significant range extensions into the region and among these are the cyprinids, Barbus chiumbeensis Pellegrin, 1936 (Figure 6C) and Barbus aloyi Roman, 1971 (Figure 7G), the amphiliid Amphilius longirostris (Boulenger, 1901), the claroteid Parauchenoglanis pantherinus (Pellegrin, 1929), and a mastacembelid tentatively identified here as Mastacembelus sexdecimspinus (Roberts and Travers, 1986). Noteworthy also, is the occurrence at all sampled sites of numerous species of "small barb", currently placed in the taxonomically problematical cyprinid genus Barbus (Berrebi et al. 1997; De Weirdt and Teugels 2007). In total 17 small barb species are now recorded from the region (Figures 6 and 7) a notably high tally for the area. In contrast, and despite the presence of seemingly suitable habitat, very few nothobranchiid killifishes were collected (Table 2), an unexpected paucity given the predominance of these fishes in other forested regions of the lower Guinean ichthyofaunal province (Stiassny et al. 2007). Equally noteworthy is the discovery of 11 taxa that appear to represent undescribed species (Table 2). In addition to two undescribed Barbus (Fig. 6A,B), nine other taxa are unassignable to currently known species (Table 2, Figures 8 and 9). Such a high number of undescribed species serves to underscore the importance of ongoing efforts to fully document the region's ichthyofauna prior to the realization of major infrastructure projects that will undoubtedly impact aquatic habitats. 


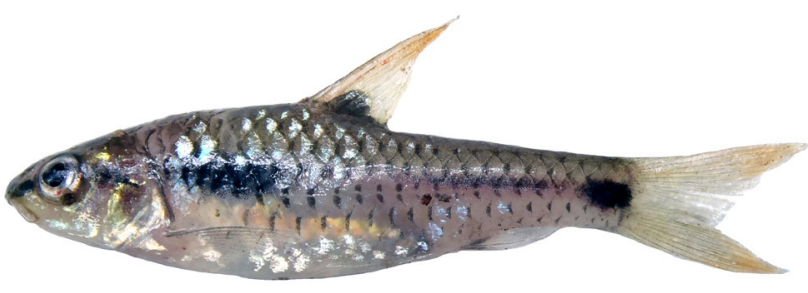

(A)
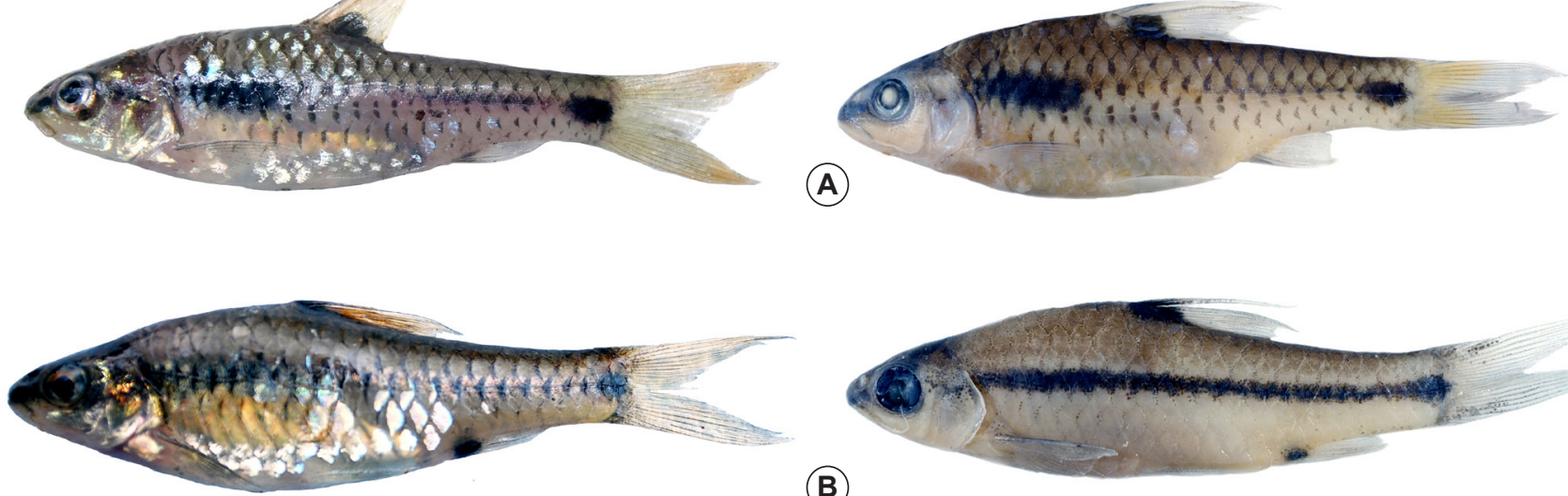

(B)
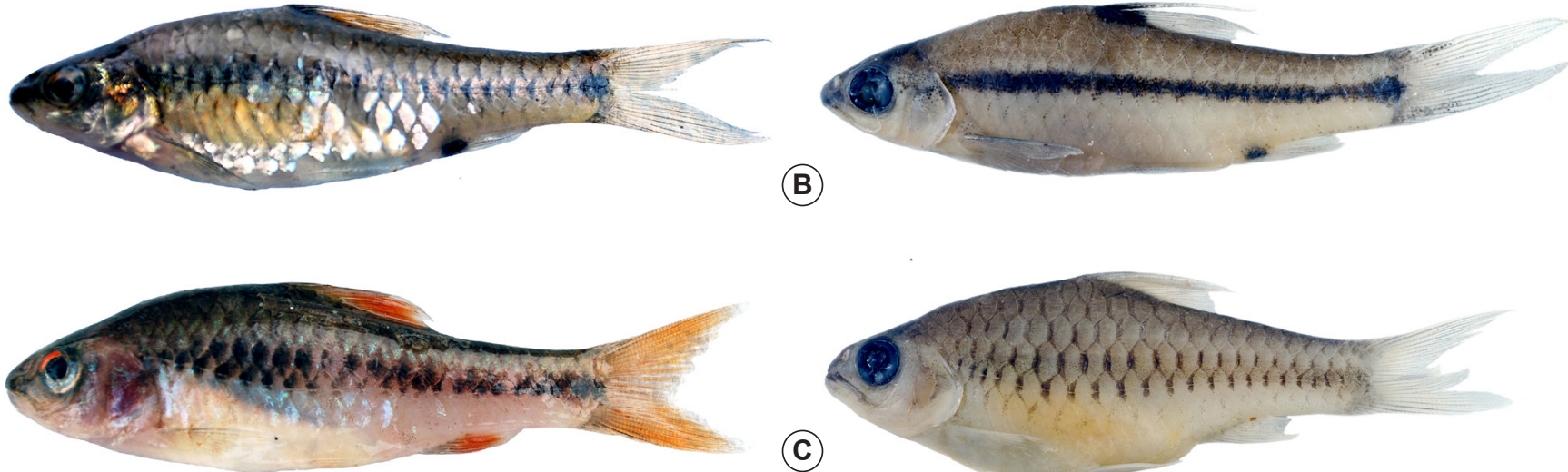

C
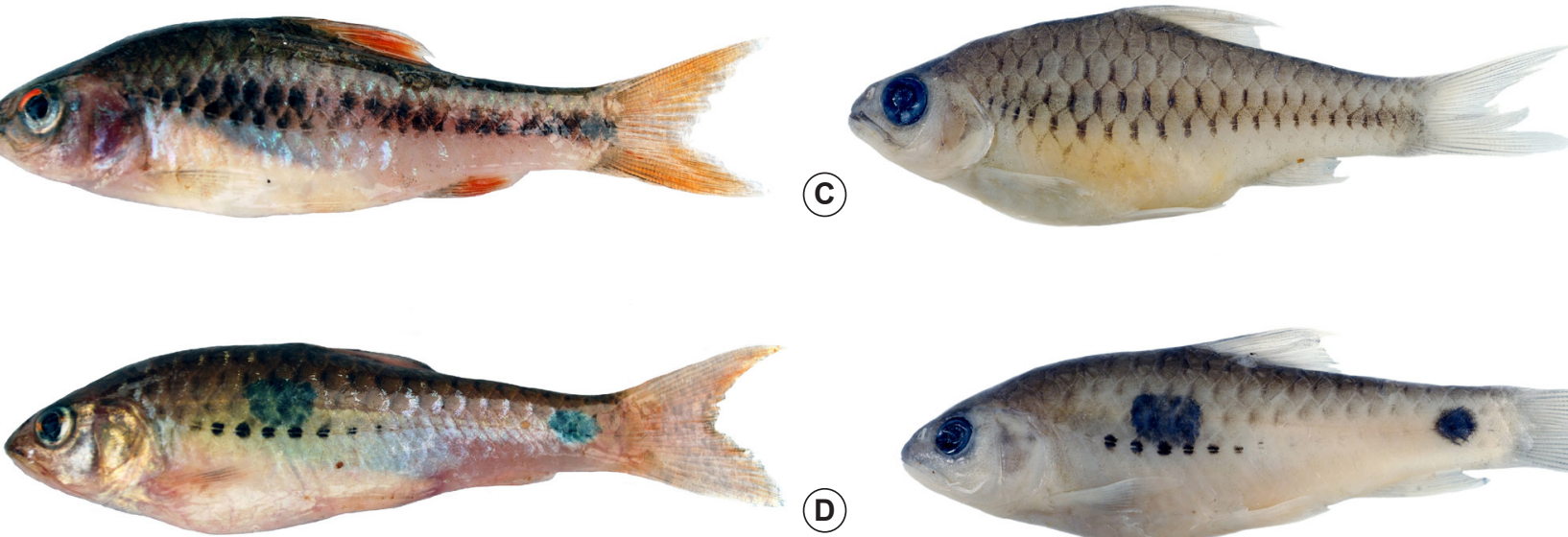

(D)
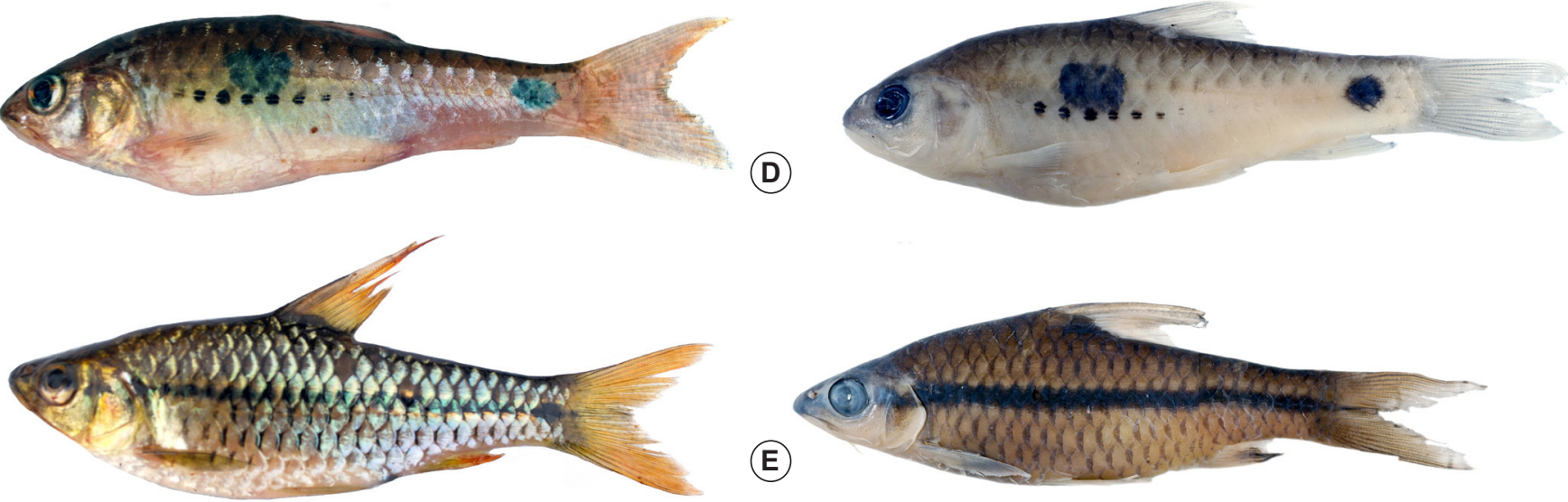

E)
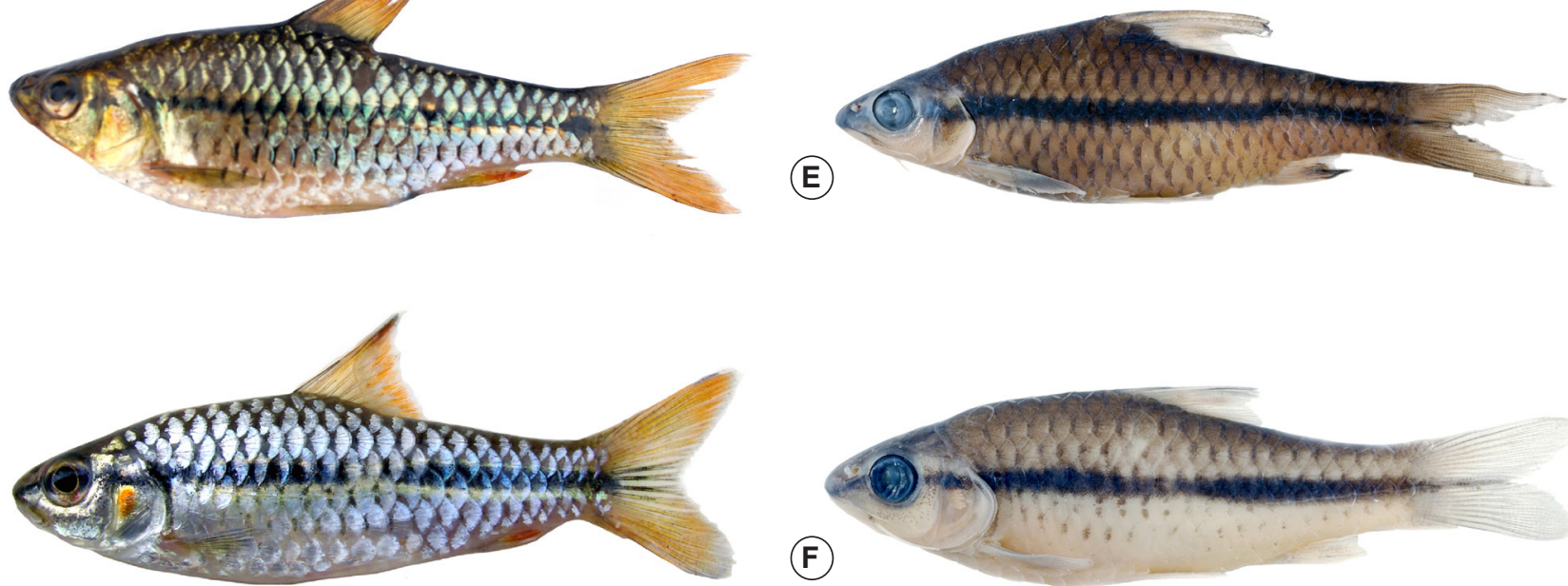

F
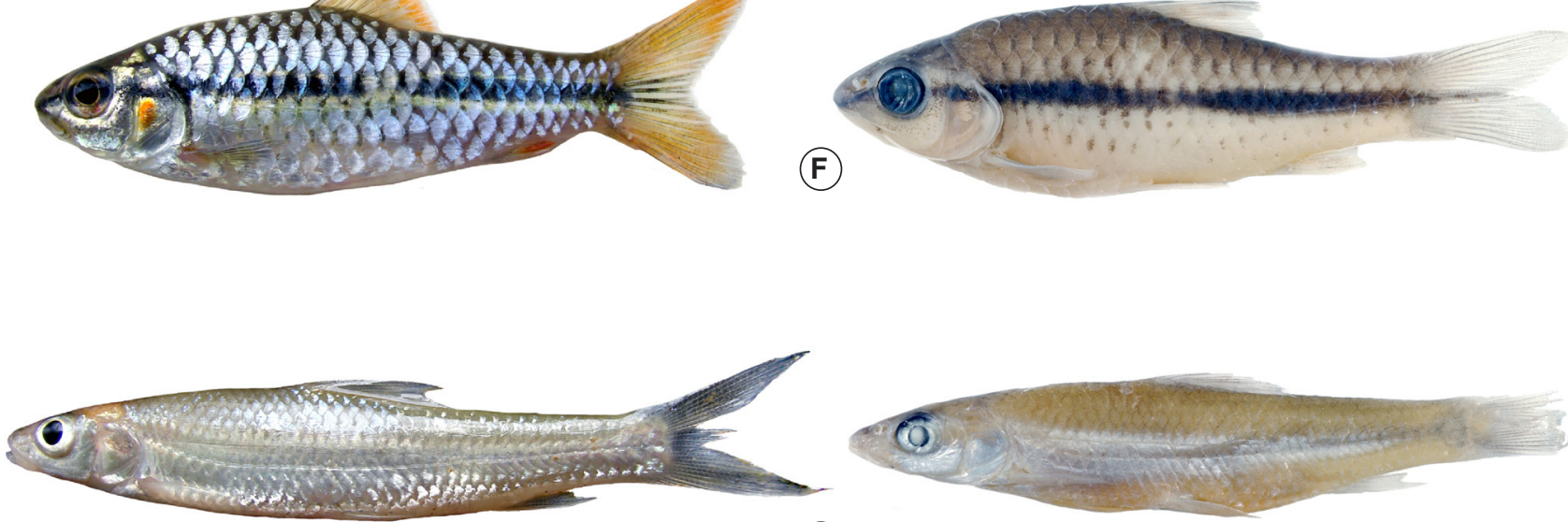

(G)

FIGURE 6. Barbus species of the region: A) Barbus sp.1, left: immediately post mortem, right: preserved; B) Barbus sp. 2, left: immediately post mortem right: preserved; C) Barbus chiumbeensis, left: immediately post mortem, right: preserved; D) Barbus camptacanthus, left: immediately post mortem, right: preserved; E) Barbus prionacanthus, left: immediately post mortem, right: preserved; F) Barbus rubrostigma, left: immediately post mortem, right: preserved. 

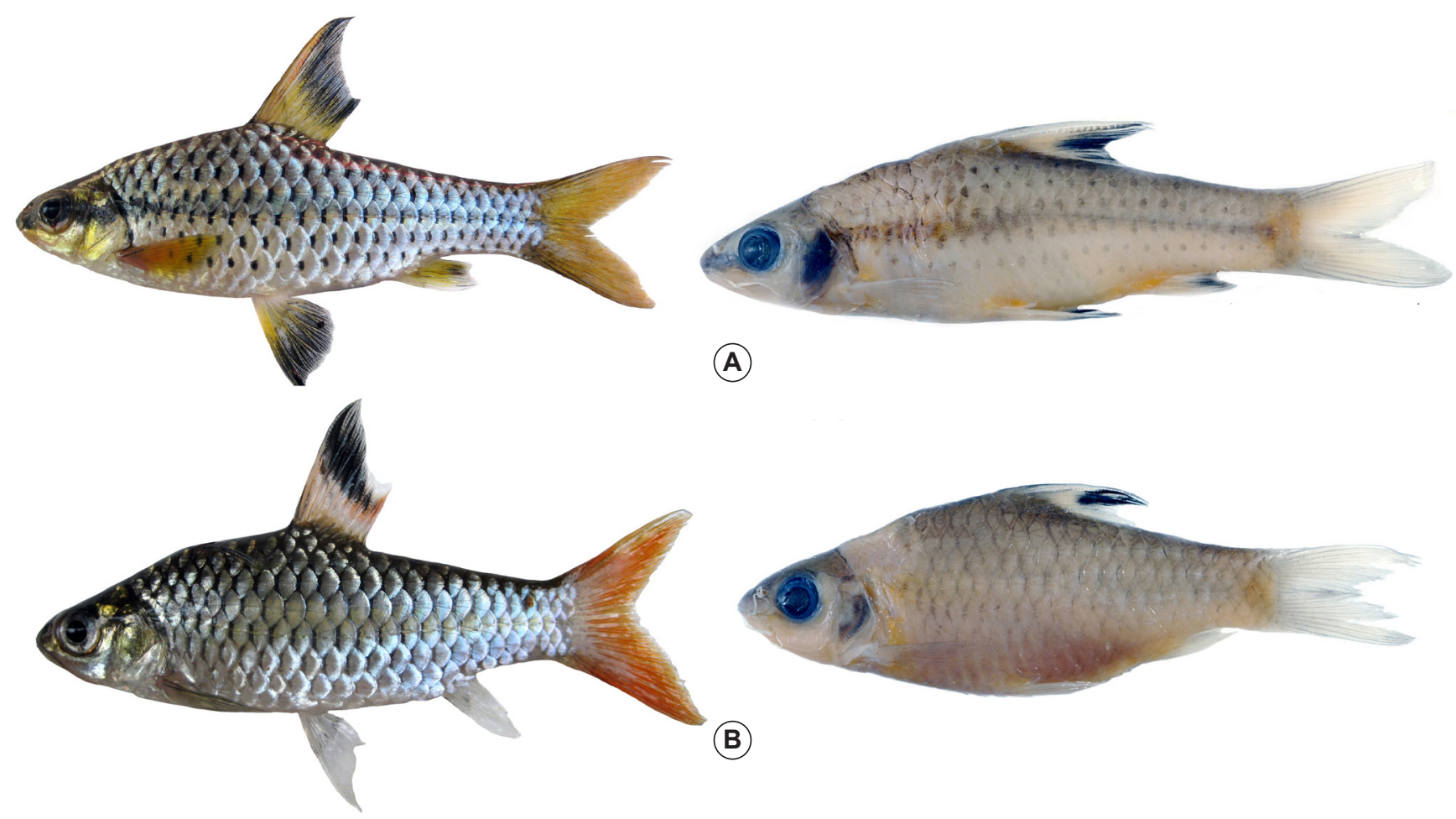

(A)
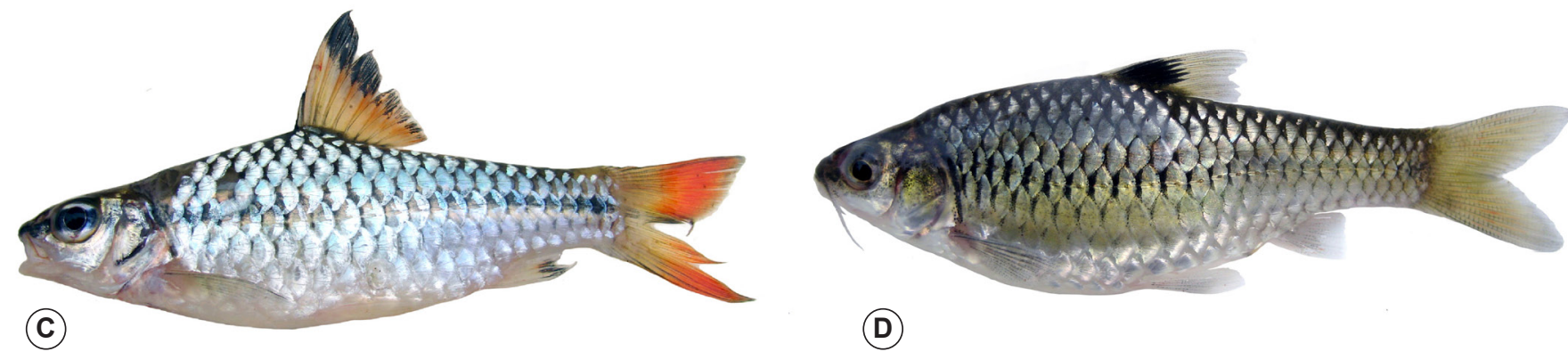

(D)
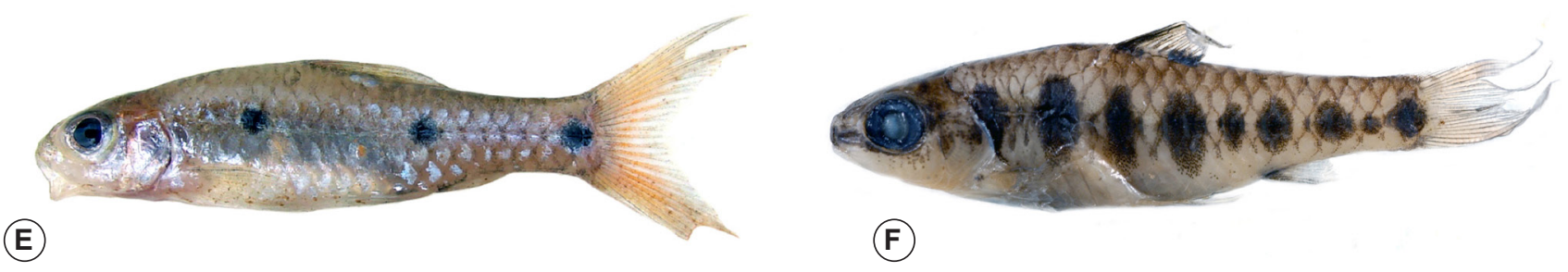

(F)

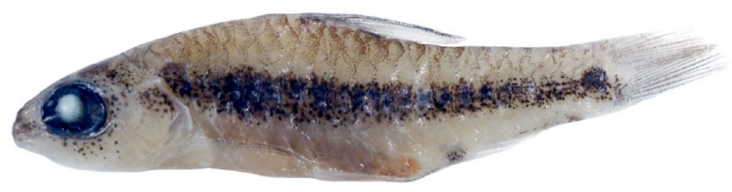

(G)

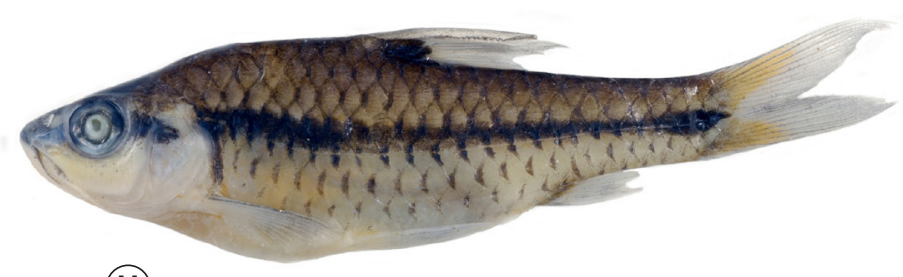

(H)
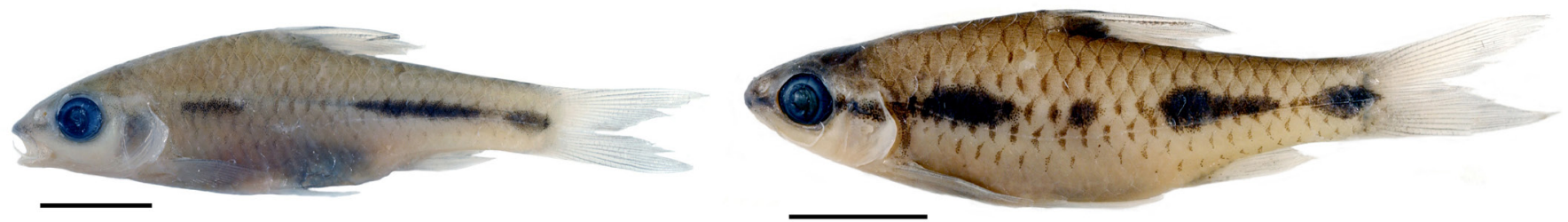

(1)

(J)

FiguRE 7. Barbus species of the region, continued: A) Barbus diamouanganai, left: immediately post mortem, right: preserved; B) Barbus guirali, left: immediately post mortem, right: preserved; C) Barbus holotaenia, immediately post mortem; D) Barbus brichardi, immediately post mortem; E) Barbus trispilomimus, immediately post mortem; F) Barbus jae, preserved; G) Barbus aloyi, preserved; H) Barbus martorelli, preserved; I) Barbus catenarius, preserved; J) Barbus kuiluensis, preserved. 
(A)
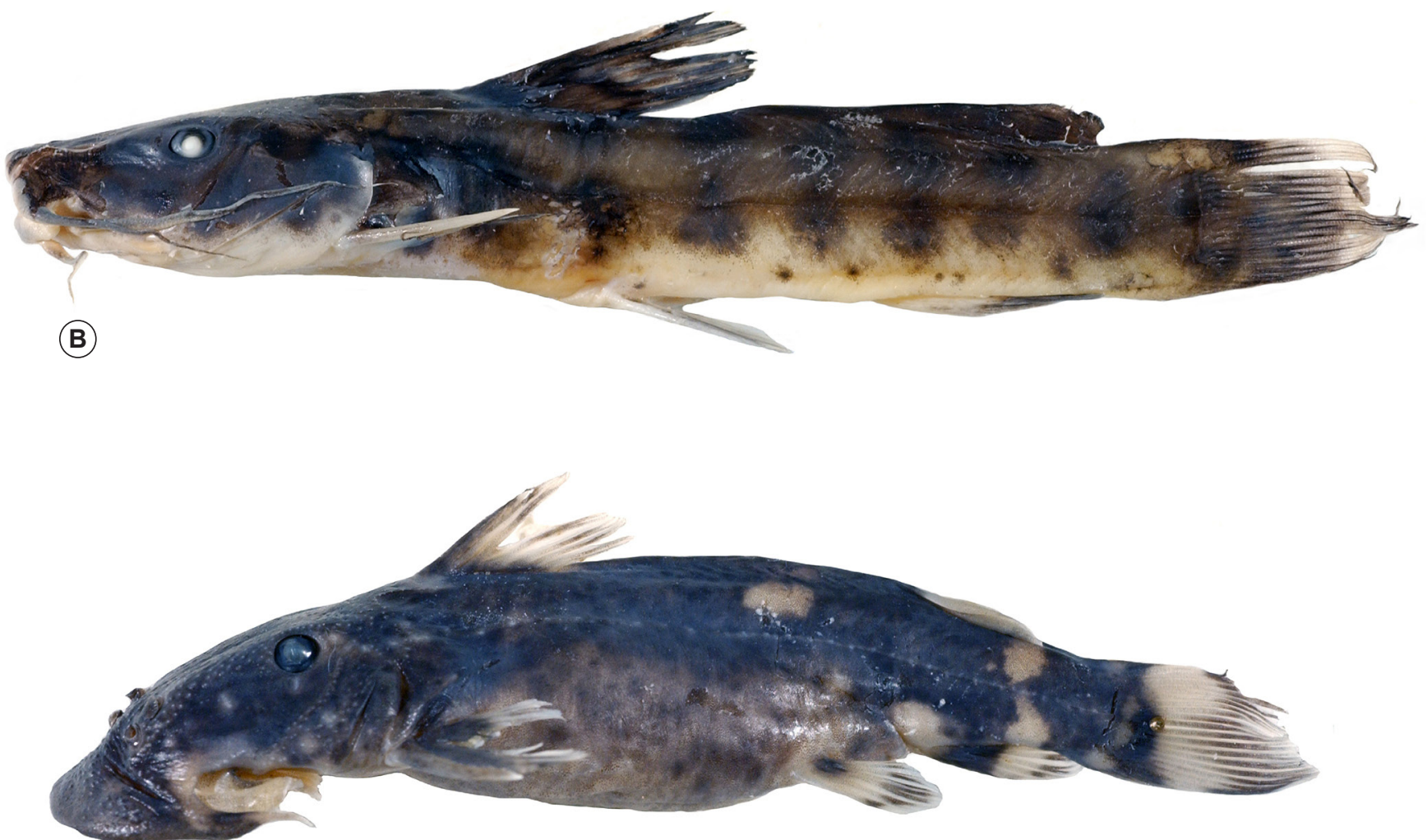

(C)

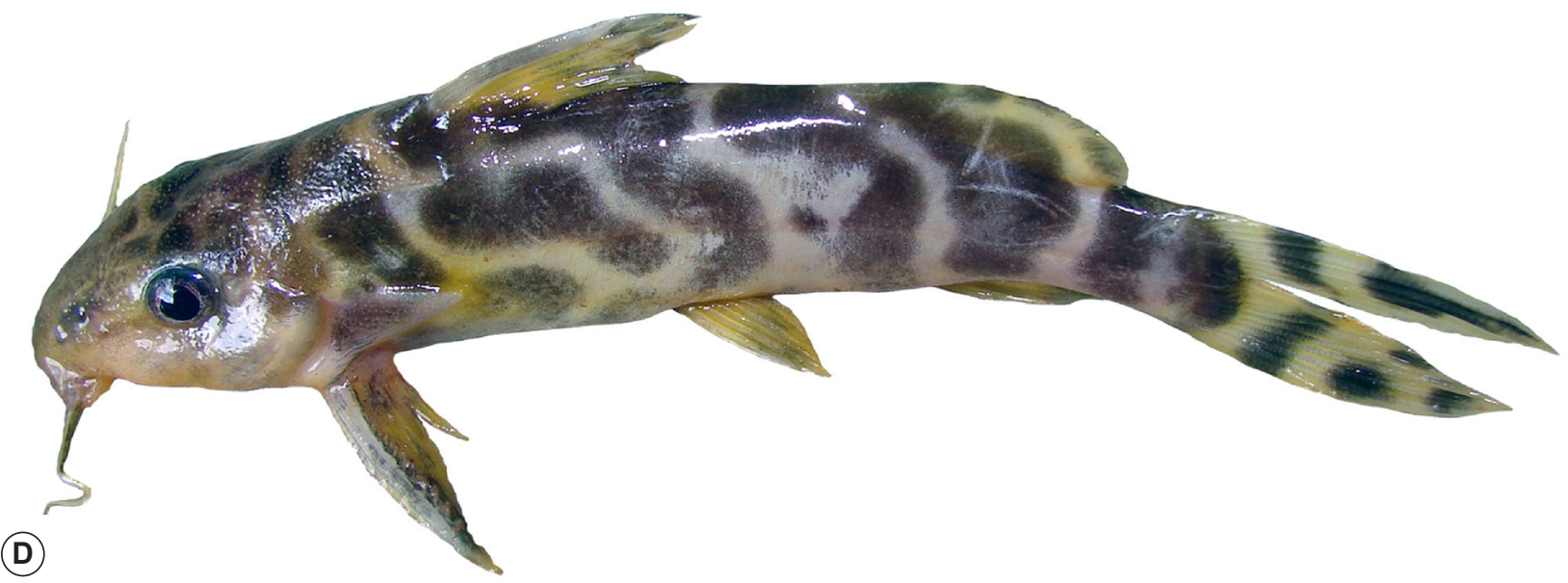

FigURE 8. Undescribed species of the region: A) Paramormyrops sp. immediately post mortem; B) Parauchenoglanis sp. preserved; C) Atopodontus sp. preserved; D) Synodontis sp. immediately post mortem. 
(A)

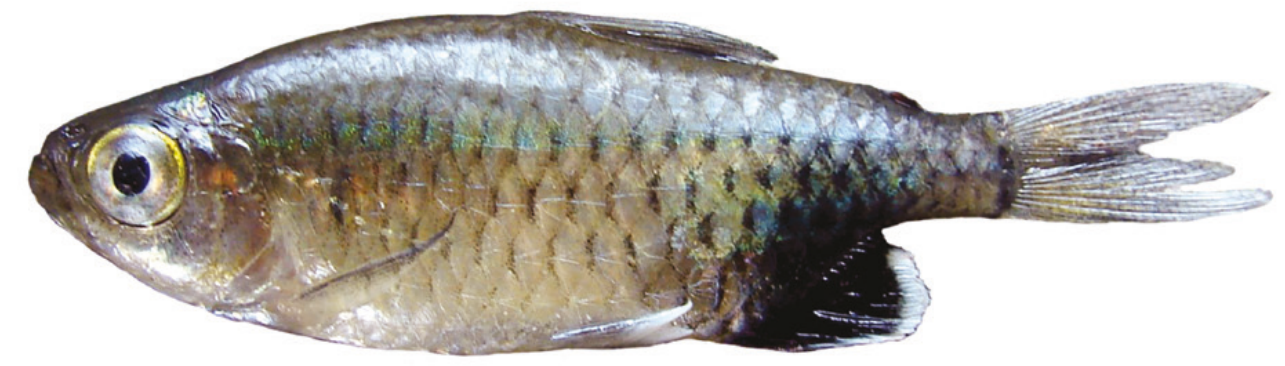

(B)

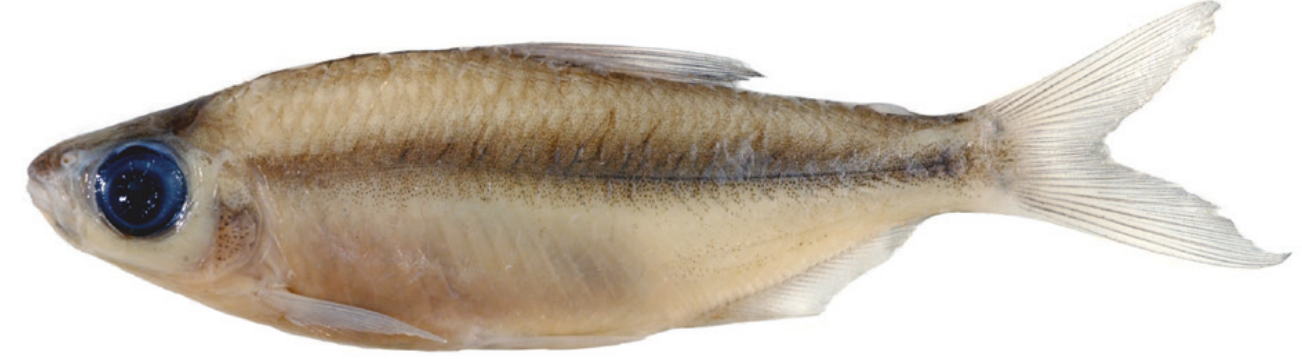

(C)

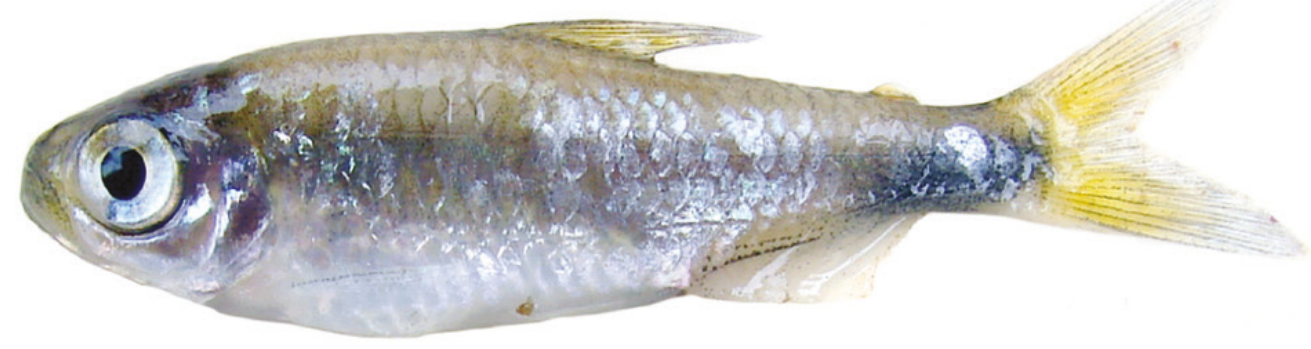

(D)

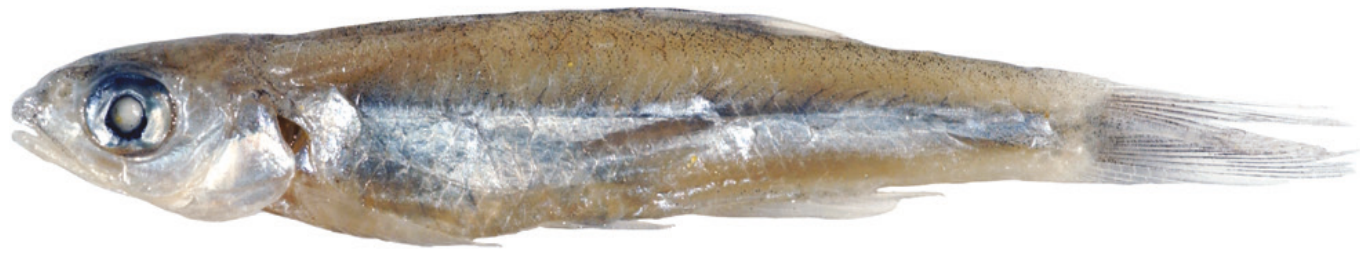

(E)

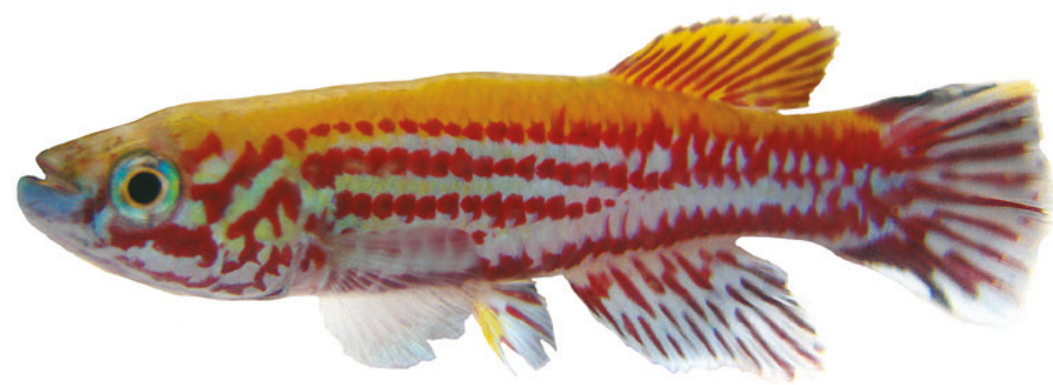

FIGURE 9. Undescribed species of the region, continued: A) Bathyaethiops sp. immediately post mortem; B) Micralestes sp. preserved; C) Rhabdalestes sp. immediately post mortem; Leptocypris sp. preserved; Aphyosemion sp. in life. 


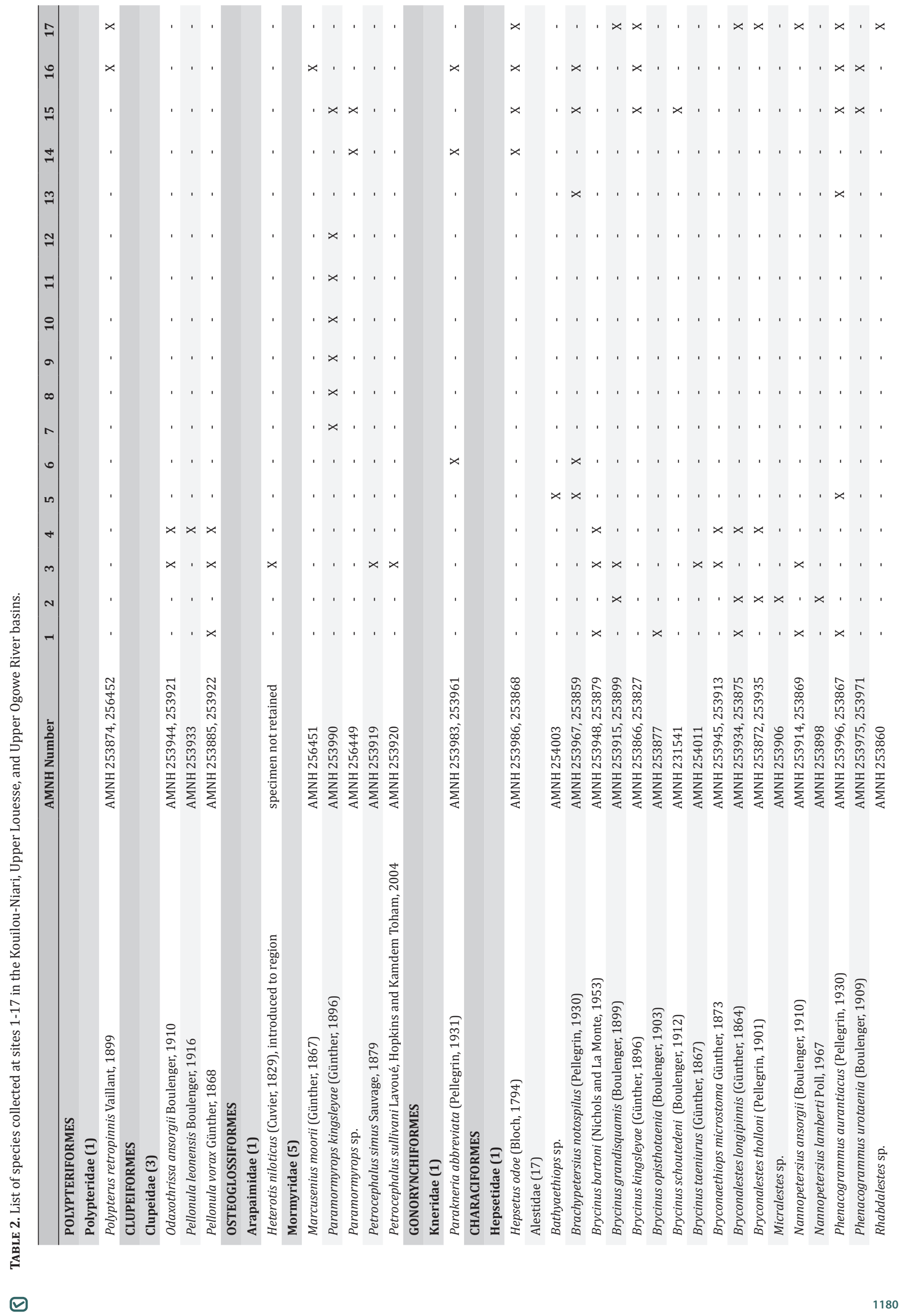




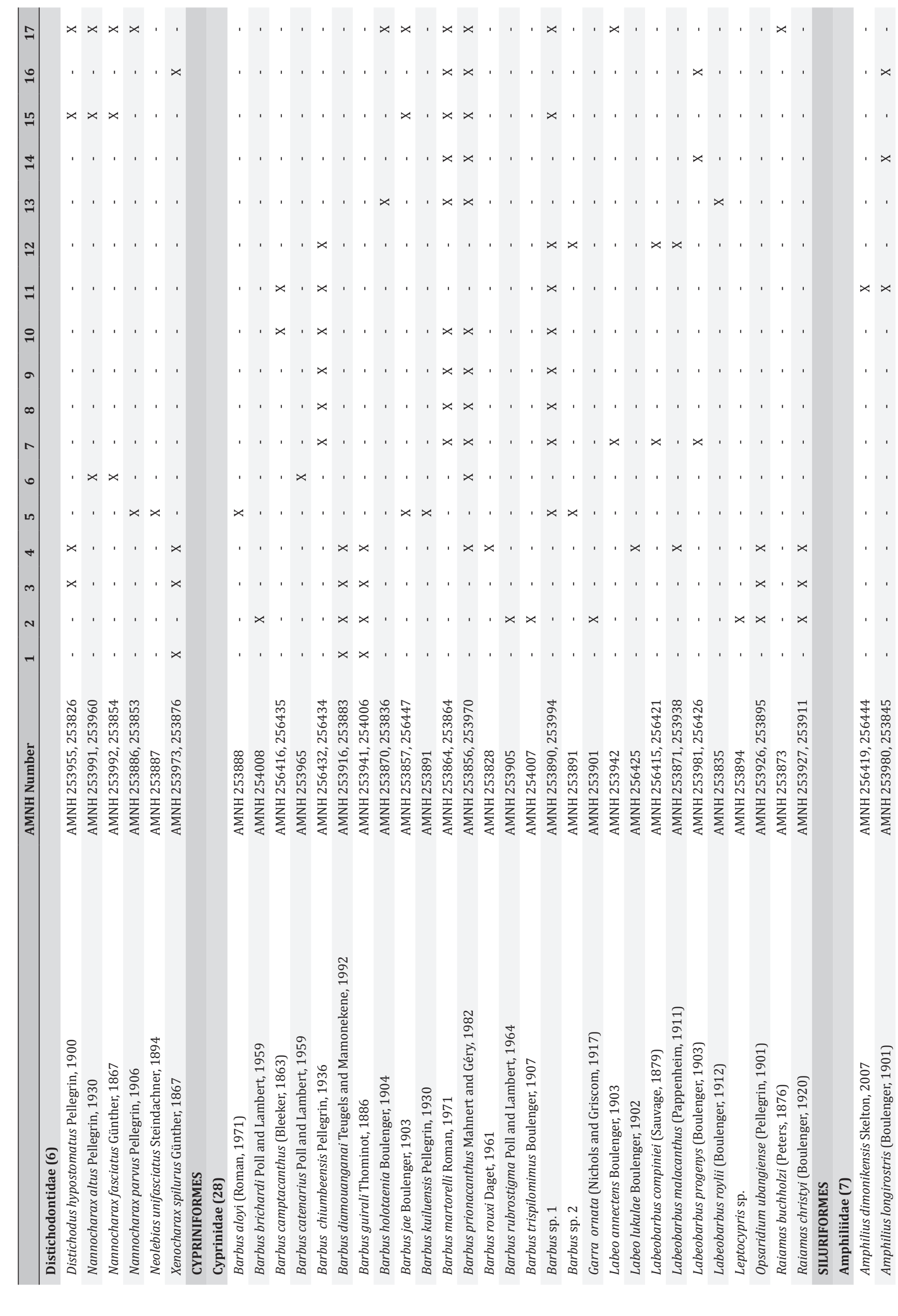




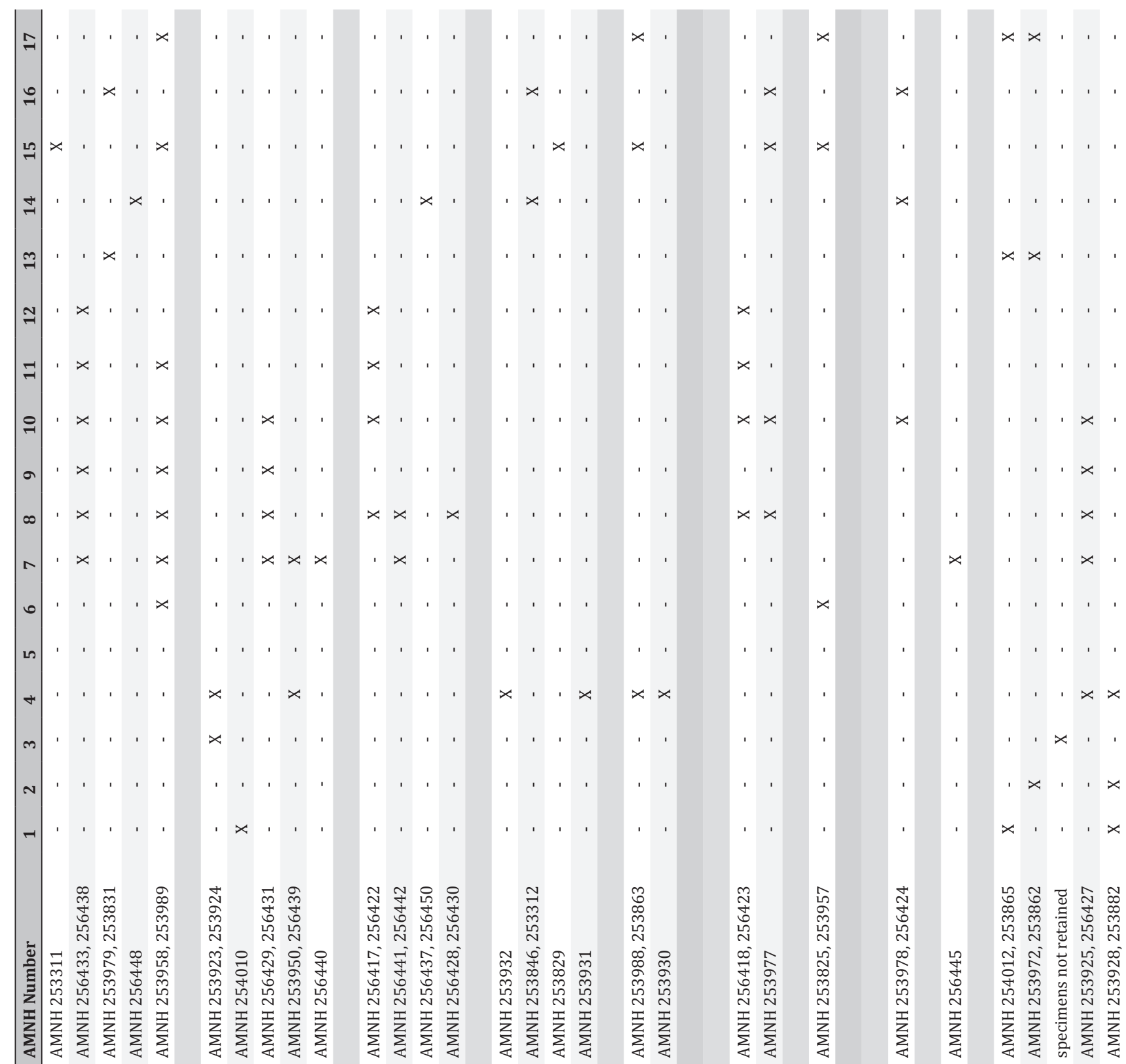

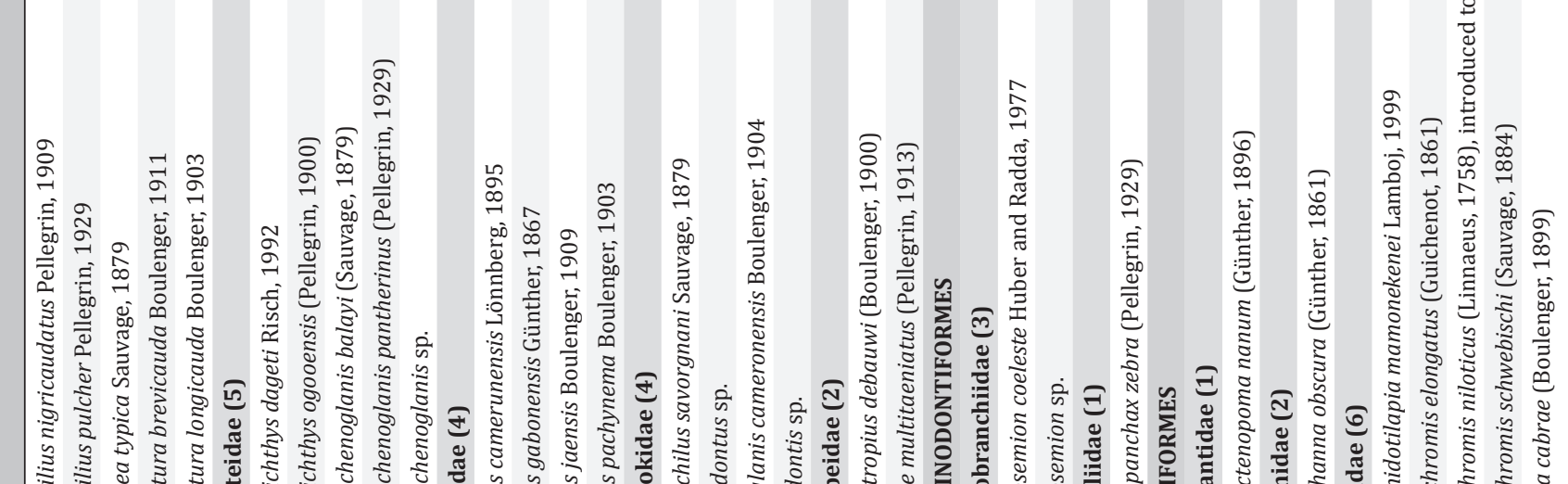

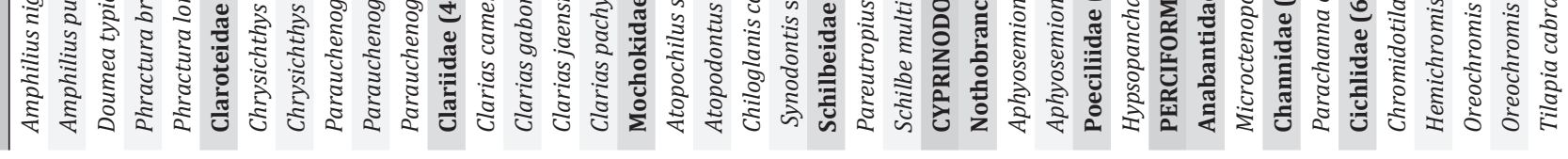




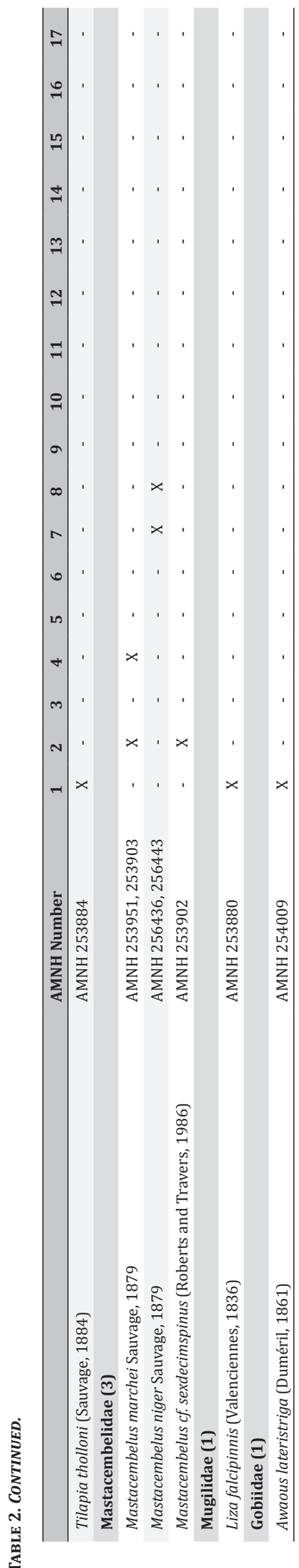

ACKNOWLEDGMENTS: Financial support was provided by the Axelrod Research Curatorship (MLJS), and by Flora Fauna \& Man, Ecological Services Ltd, Pretoria (South Africa) and Hydrobiology Pty Ltd, Queensland (Australia) who provided logistical and financial support for this inventory of fishes. Thanks also to Martin Bassafoula and Valdie Boukaka for their assistance in the field. The invaluable taxonomic input of Carl Hopkins and John Friel (Cornell University), and Jouke van der Zee (Africa Museum, Tervuren) (Mormyridae, Mochokidae and Nothobranchiidae respectively) is gratefully acknowledged. Finally, our thanks to Barbara Brown and Radford Arrindell (AMNH) for help with accessioning and cataloging specimens.

\section{LITERATURE CITED}

AFS/AIFRB/ASIH. 2003. Guidelines for the use of fishes in research Document accessible at http://www.asih.org/files/fish\%20 guidelines.doc. Captured on July 27, 2012.

Berrebi, P., M. Kottelat, P. Skelton and P. Rab. 1996. Systematics of Barbus: state of the art and heuristic comments. Folia Zoologica 45: 5-12.

Brooks, E.G.E., D.J. Allen and W.R.T. Darwell. 2011. The Status and Distribution of Freshwater Biodiversity in Central Africa. Gland, Switzerland and Cambridge, UK: IUCN. 126p.

De Weirdt, D.E. and G.G. Teugels. 2007. Genus Barbus; p.471-511 In M.L.J. Stiassny, G.G. Teugels and C.D. Hopkins (ed.) The Fresh and Brackish Water Fishes of Lower Guinea, West-Central Africa. Volume I. Paris: IRD Éditions.

Eschmeyer, W.N. 2010. Catalog of Fishes. Electronic database accessible at http://research.calacademy.org/ichthyology/catalog/fishcatmain. asp Captured 26 July 2012.

Lang, M.A. and C.C. Baldwin 1996. Methods and techniques of underwater research. Proceedings of the American Academy of Underwater Sciences Sixteenth Annual Scientific Diving Symposium. Washington DC: Smithsonian Institution. 236 p.

Stiassny, M.L.J., G.G. Teugels and C.D. Hopkins (ed.) 2007. The Fresh and Brackish Water Fishes of Lower Guinea, West-Central Africa. Volume I (800pp), Volume II (603 p). Paris: IRD Éditions.

Vicat J.P. and P. Gioan 1989. La chaîne précambrienne du Mayombe en République Populaire du Congo: Géologie, métallogénie, perpectives de développement. p. 17-45 In J. Sénéchal, M. Kabala and F. Fournier (ed.) Revue des connaissances sur le Mayombe. République Populaire du Congo,. Paris: PNUD, UNESCO, MAB.

RECEIVED: July 2012

ACCEPTED: Ocotber 2012

Published ONLINE: December 2012

EDITORIAL RESPONSIBILITY: Javier A. Maldonado O. 